\title{
Presence and molecular characterization of cucumber mosaic virus on safflower in Serbia
}

\author{
Dragana Milošević ${ }^{*} \cdot$ Maja Ignjatov ${ }^{1} \cdot$ Ana Marjanović Jeromela $\cdot$ Zorica Nikolić ${ }^{1} \cdot$ Gordana \\ Tamindžić ${ }^{1}$. Dragana Miljaković ${ }^{\cdot}$ Ivana Stanković ${ }^{2}$
}

${ }^{1}$ Institute of Field and Vegetable Crops, Maksima Gorkog 30, 21000 Novi Sad, Serbia

${ }^{2}$ University of Belgrade, Faculty of Agriculture, Nemanjina 6, 11080, Belgrade-Zemun, Serbia

\begin{abstract}
Summary: Safflower (Carthamus tinctorius L.) is an important oilseed crop belonging to the family Asteraceae. A total of 46 safflower samples were collected from Srbobran locality (South Bačka District) in Serbia in 2015 and analysed for the presence of cucumber mosaic virus (CMV), alfalfa mosaic virus (AMV), and lettuce mosaic virus (LMV), using commercial double-antibody sandwich (DAS)-ELISA kits. Both viruses, CMV and AMV, were detected serologically in the collected samples. None of the analysed samples was found to be positive for LMV. The presence of CMV was further confirmed by mechanical transmission to test the plants including Chenopodium quinoa, C. amaranticolor, Nicotiana glutinosa, and Datura stramonium as well as C. tinctorius, confirming the infectious nature of the disease. Molecular detection of CMV was performed by amplification of a $871 \mathrm{bp}$ fragment in all the tested samples, using the specific primers CMVCPfwd/CMVCPrev that amplify the entire coat protein (CP) gene and part of 3'- and 5'-UTRs of CMV RNA 3. The RT-PCR products derived from the isolates 290Saff and 294Saff were sequenced (MH577791 and MH577792, respectively) and compared with the CMV sequences available in GenBank. Phylogenetic analysis based on CP gene sequences showed clustering of the selected isolates into three subgroups: IA, IB and II. Serbian CMV isolates found in safflower belong to subgroup II. To our knowledge, this is the first report on CMV infection of safflower in Serbia, which has the potential to cause substantial damage to safflower production and pose a threat to other economic crops grown in Serbia.
\end{abstract}

Key words: cucumber mosaic virus, DAS-ELISA, RT-PCR, safflower

\section{Introduction}

Safflower (Carthamus tinctorius L., family Asteraceae) has been grown for centuries, primarily for its colourful petals, and used as a food colouring, flavouring agent, for vegetable oil production and for textile dye preparation (Esendal, 2001; Ekin, 2005). Considerable interest for the use of safflower as forage has recently occurred (Landau et al., 2005). Safflower has been receiving a lot of publicity, not so much for its colourful petals, but because it is regarded as one of the most

Corresponding author:

dragana.milosevic@ifvcns.ns.ac.rs

Acknowledgments:

This research was supported by the Ministry of Education, Science and Technological Development of the Republic of Serbia, grant numbers: 451-0368/2020-14/200032 and 451-03-68/2020-14/200116.

\section{Cite this article:}

Milošević D., Ignjatov M., Marjanović Jeromela A., Nikolić Z., Tamindžić G., Miljaković D., Stanković I. (2020). Presence and molecular characterization of cucumber mosaic virus on safflower in Serbia. Ratar. Povrt., 57 (2), 49-54. important sources of vegetable oils. Safflower seeds contain nearly $35-50 \%$ oil, $15-20 \%$ protein and $35-45 \%$ hull fraction (Dobrinoiu et al., 2011).

As a result of breeding in the Institute of Field and Vegetable Crops (IFVCNS) in Novi Sad, Serbia, a collection of several genotypes of safflower has been formed and so far two varieties NS Lana and NS Una have been registered in the Republic of Serbia. Moreover, the demand for safflower breeding and its commercial establishment comes as a result of changed production conditions which include long drought periods during the summer season, when safflower, similarly to sunflower, produces higher yields than most other crops. As support to the breeding programs, research has been conducted in order to examine the presence of disease causal agents and their effect on yield and quality of safflower seeds.

Safflower is attacked by many diseases caused by fungi, bacteria, viruses, and suffers from physiological disorders due to abiotic stresses (Patil et al., 1993). Safflower is a natural host of cucumber mosaic virus (CMV), alfalfa mosaic virus (AMV), lettuce mosaic virus (LMV) (Klisiewiez, 1965,1966; Tomas, 1981), turnip 
mosaic virus (Klisiewiez, 1983), and tobacco streak virus (TSV) (Chander Rao et al., 2003).

CMV belongs to the genus Cucumovirus in the family Bromoviridae and causes significant damage to many agricultural crops including vegetables, ornamentals, and legumes resulting in devastating yield losses (Palukaitis \& Garcia-Arenal, 2003). CMV is transmitted by numerous of aphid species, notably Aphis gossypii and Myzus persicae, in a non-persistent manner as well as by seed of several hosts (Francki et al., 1979). The genome of CMV comprises three single-stranded genomic RNAs (RNA 1, 2, 3) and two subgenomic mRNA (RNA 4, RNA4A) (Palukaitis et al., 1992). According to serological relationships, nucleic acid hybridization data, and molecular analyses of the genomic RNAs, CMV isolates are divided into subgroups I and II (Anderson et al., 1995; Palukaitis \& Garcia-Arenal, 2003). Furthermore, subgroup I is divided into two subgroups IA and IB with $92 \%$ to $95 \%$ nucleotide homology (Palukaitis et al., 1992; García-Arenal \& Palukaitis, 2008)

Considering the frequent presence of CMV on various plant species in Serbia, after the first detection of AMV infecting safflower at Rimski Šančevi in Serbia (Milošević et al., 2015a), a survey was conducted in order to establish the presence and distribution of safflower viruses in Serbia, as well as to determine the genetic relationship of Serbian safflower CMV isolates with isolates from other parts of the world.

\section{Material and Methods}

\section{Sample collection}

During 2015 the survey was carried out in order to determine the occurrence and distribution of viruses infecting safflower at the oil species collection. After visual inspection, a total of 46 samples of symptomatic safflower plants were collected from the localities at Srbobran (South Bačka District) in the Province of Vojvodina. The samples of safflower plants comprised of leaves which exhibited the typical symptoms of viral infection, such as mosaic infection, chlorotic mottling and leaf deformation. Samples were transported and stored at $4^{\circ} \mathrm{C}$ until testing by ELISA or stored at $-20^{\circ} \mathrm{C}$ until RNA extraction and RT-PCR.

Double-antibody sandwich ensyme linked immunosorbent assay (DAS)-ELISA

Collected samples were serologically tested on the presence of CMV, AMV and LMV utilizing doubleantibody sandwich (DAS)-ELISA kits using polyclonal antisera from Loewe Biochemica $\mathrm{GmbH}$ (Germany) according to the manufacturer's instructions. Extracts from fresh leaves were ground in an extraction buffer at a ratio of 1:10 (w/v). After addition of the substrate (1 $\mathrm{mg} / \mathrm{ml}$ of $\mathrm{p}$-nitrophenyl phosphate, Sigma-Aldrich, USA), the plates were incubated at room temperature for 2 hours and the extinction was measured at $405 \mathrm{~nm}$
(A405) using an ELISA plate reader (Multiscan Ascent, Finland). Commercial positive and negative controls and extracts from healthy safflower tissue were included in each test. Samples were considered to be positive when the absorbance values were at least two times higher than the negative controls.

\section{Mechanical transmission}

Crude sap extracted from the leaves of two serologically positive samples (290Saff and 294Saff) using $0.01 \mathrm{M}$ phosphate buffer ( $\mathrm{pH}$ 7) was mechanically inoculated onto five plants each of Chenopodium quinoa, C. amaranticolor, Nicotiana glutinosa, and Datura stramonium as well as Carthamus tinctorius. All test plants were inoculated at the 3 to 4 true-leaf stage. The inoculated plants were grown in glasshouse conditions and symptoms on inoculated plants were recorded in 18-20 days after inoculation. All inoculated plants were assayed by DAS-ELISA test to confirm CMV presence.

Reverse transcription polymerase chain reaction (RT-PCR)

Conventional RT-PCR was conducted for further confirmation of the serological findings. Total RNAs from the leaf tissue were extracted from $100 \mathrm{mg}$ by the RNeasy Plant Mini Kit (Qiagen, Germany) according to the manufacturer's instructions, and used as template in RT-PCR. RT-PCR was performed using the One-Step RT-PCR Kit (Qiagen, Germany) using CMV specific primer pair CMVCPfwd/CMVCPrev (Milojević et al., 2012) which amplifies an 871-bp fragment of the entire coat protein $(\mathrm{CP})$ gene.

The RT-PCR reaction mixture included $400 \mu \mathrm{M}$ each of the four dNTPs, $1 \mu$ l of RT-PCR enzyme mix, $0.6 \mu \mathrm{M}$ each primer and $1 \mu \mathrm{l}$ extracted RNA in a final volume of $25 \mu \mathrm{l}$. Amplifications were performed in a thermal cycler (Eppendorf, Germany). Reverse transcription was performed at $50^{\circ} \mathrm{C}$ for $30 \mathrm{~min}$, followed by an initial PCR denaturation step at $95^{\circ} \mathrm{C}$ for $15 \mathrm{~min}$, and 35 cycles of denaturation on $94^{\circ} \mathrm{C}$ for $60 \mathrm{~s}$, annealing on $52^{\circ} \mathrm{C}$ for $60 \mathrm{~s}$, and extension on $72^{\circ} \mathrm{C}$ for $60 \mathrm{~s}$; and a final extension at $72^{\circ} \mathrm{C}$ for $10 \mathrm{~min}$. The Serbian isolate of CMV (GenBank Accession No. KC288146) from pepper and a healthy safflower plant were used as the positive and the negative control, respectively.

RT-PCR products were separated using electrophoresis on $1 \%$ agarose gel containing ethidium bromide $(0.5 \mathrm{~g} / \mathrm{mL})$. The expected sizes of the amplified fragments were estimated by comparison with O’RangeRulerTM 100 bp DNA Ladder, ready-to-use (Fermentas, Lithuania). The agarose gel was visualised in a UV transilluminator, and the images were captured with the DOC PRINT system (Vilber Lourmat, USA).

\section{Sequencing and phylogenetic analysis}

The amplified products from the selected isolates were sequenced in both directions (ABI 3730XL 
Automatic Sequencer, Macrogen, Korea), using the same primers as in RT-PCR directly after purification, with a QIA quick PCR Purification Kit (Qiagen, Germany). The obtained sequences of the Serbian CMV isolates were compared with the previously reported isolates available in the GenBank (http:// www.ncbi.nlm.nih.gov/BLAST/), using the ClustalW program (Thompson et al., 1994) and MEGA5 software (Tamura et al., 2011). A p-distance model was applied for nucleotide (nt) and deduced amino acid (aa) sequence analyses.
Phylogenetic tree was created using $40 \mathrm{CP}$ sequences of CMV isolates (Table 1) which were retrieved from GenBank and two CMV sequences generated in this study by the use of Neighbour-Joining method implemented in MEGA5 software. The reliability of the obtained tree was evaluated using the bootstrap analysis with 1000 replicates, and bootstrap values $<50 \%$ were collapsed. Intra- and inter-group diversity values were calculated as the average genetic distance using Kimura 2-parameter model Gamma distributed $(\mathrm{K} 2+\mathrm{G})$ which was chosen as the best-fitting model of nt substitution.

Table 1. CP gene sequences of Cucumber mosaic virus isolates used in the phylogenetic analysis

\begin{tabular}{|c|c|c|c|c|}
\hline Virus & Isolate & Country & Host & Gen Bank Acc. No. \\
\hline CMVa & 290Saff & Serbia & Carthamus tinctorius & MH577791 \\
\hline $\mathrm{CMV}^{\mathrm{a}}$ & 294Saff & Serbia & Carthamus tinctorius & MH577792 \\
\hline CMV & $702-07$ & Serbia & Nicotiana tabacum & GQ340670 \\
\hline CMV & 151-08 & Serbia & Cucurbita pepo 'Olinka' & HМ065509 \\
\hline CMV & $115-08$ & Serbia & Cucurbita pepo 'Olinka' & НМ065510 \\
\hline CMV & $232 \mathrm{Mrg}$ & Serbia & Calendula officinalis & KP034963 \\
\hline CMV & MAD 99/4 & Spain & Cucurbita pepo & AJ829770 \\
\hline CMV & MAD96/1 & Spain & Cucumis melo & AJ829768 \\
\hline CMV & $\mathrm{I} 17 \mathrm{~F}$ & France & / & Y18137 \\
\hline CMV & 207 & Australia & Solanum lycopersicum & AJ585517 \\
\hline $\mathrm{CMV}$ & Q & Australia & Capsicum annuum & M21464 \\
\hline CMV & Fny & USA & Cucumis melo & D10538 \\
\hline CMV & CMV-P6 & USA & Nicotiana tabacum & D10545 \\
\hline CMV & CMV-FC & USA & Nicotiana tabacum & D10544 \\
\hline CMV & PR36 & USA & / & M98500 \\
\hline CMV & Ixora & USA & Ixora sp. & U20219 \\
\hline CMV & $\mathrm{K}$ & USA & $/$ & AF127977 \\
\hline CMV & S & USA & Cucurbita pepo & AF063610 \\
\hline CMV & / & Colombia & Musa sp. & U32859 \\
\hline CMV & Cas & Poland & Lilium sp. & DQ018286 \\
\hline CMV & Simp2 & Poland & Lilium sp. & FJ621495 \\
\hline CMV & Ly2 & Korea & Lilium longiflorum & AJ296154 \\
\hline $\mathrm{CMV}$ & ABI & Korea & Gladiolus sp. & L36525 \\
\hline CMV & M-48 & Taiwan & / & D49496 \\
\hline CMV & Oahu & Hawaii & Musa sp. & U31220 \\
\hline CMV & $\mathrm{KM}$ & Japan & Cucumis melo & AB004780 \\
\hline CMV & D8 & Japan & Raphanus sativus & AB004781 \\
\hline $\mathrm{CMV}$ & Y & Japan & Nicotiana tabacum & D12499 \\
\hline $\mathrm{CMV}$ & Pepo & Japan & Cucurbita pepo & AF103991 \\
\hline CMV & $\mathrm{C} 7-2$ & Japan & / n l n & D42079 \\
\hline CMV & 42CM & Japan & Cucumis sativus & AB368498 \\
\hline CMV & M2 & Japan & / & AB006813 \\
\hline CMV & Kin & United Kingdom & / & Z12818 \\
\hline CMV & P1 & China & / & AJ006988 \\
\hline $\mathrm{CMV}$ & Phy & China & / & DQ412732 \\
\hline CMV & Cah1 & China & Canna sp. & FJ268746 \\
\hline CMV & CTL & China & Brassica chinensis & EF213025 \\
\hline CMV & $\mathrm{Cb} 7$ & China & Solanum lycopersicum & EF216867 \\
\hline CMV & Tsh & China & Solanum bycopersicum & EF202597 \\
\hline CMV & CS & China & Arachis bypogaea & AY429437 \\
\hline CMV & $\mathrm{Ca}$ & China & Arachis bypogaea & AY429432 \\
\hline CMV & Vir & Italy & Capsicum annuum & HE962480 \\
\hline PSVb & ER & India & Vigna unguiculata & $\mathrm{U} 15730$ \\
\hline
\end{tabular}

a - Isolates originating from safflower from Serbia; b - Peanut stunt virus sequence used as outgroup. 


\section{Research results}

Virus detection and symptomatology in the field

During the visual inspection of the safflower field in 2015, mosaic was the most frequent symptom, varying from mild to severe, followed by chlorotic mottling and leaf deformations. In total, the CMV infection was detected in 32 of 46 (69.57\%), while AMV was detected in 15 of 46 (32.61\%) of serologically tested samples. Single infections were the most frequent infection type $(67.39 \%)$ and CMV $(52.17 \%)$ was the most common, while mixed infection was found in only $17.39 \%$ of the tested samples. All tested samples were negative for LMV. Examined plants with single CMV infection exhibited mild to severe mosaic infection on the leaves, leaf distortion, and growth reduction. Plants infected with AMV expressed bright yellow spots on the leaves. Mixed infections caused a variety of symptoms, such as more intensive symptoms of mosaic, yellowing and leaf malformations which were not of diagnostic value in preliminary evaluation.
CMV is a very common plant virus that infects many plant families and can cause significant economic losses in many fruit, vegetable, ornamental, and horticultural crops (Akhtar et al., 2010; Dubey et al., 2010; Jalender et al., 2015). Natural occurrence of CMV in safflower was reported by Fletcher (2001), and Ravinder et al. (1992). Chenulu et al. (1971) and Chauhan and Singh (1979) reported the seed borne nature of CMV in safflower. Because CMV is seed transmitted, safflower seeds should come from certified production, in order to prevent viral transmission through seeds and thus cause greater damage to the production. Also, as a perennial plant, safflower represents a potential virus reservoir and an additional source of inoculums, used in order to recognize the known host range and prevalence of CMV in weed hosts. This investigation provides the first information on the presence of CMV on safflower in Serbia.

Phylogenetic tree, based on 42 sequences of the CP genes of CMV isolates from different host plants, showed separation of the selected isolates into three

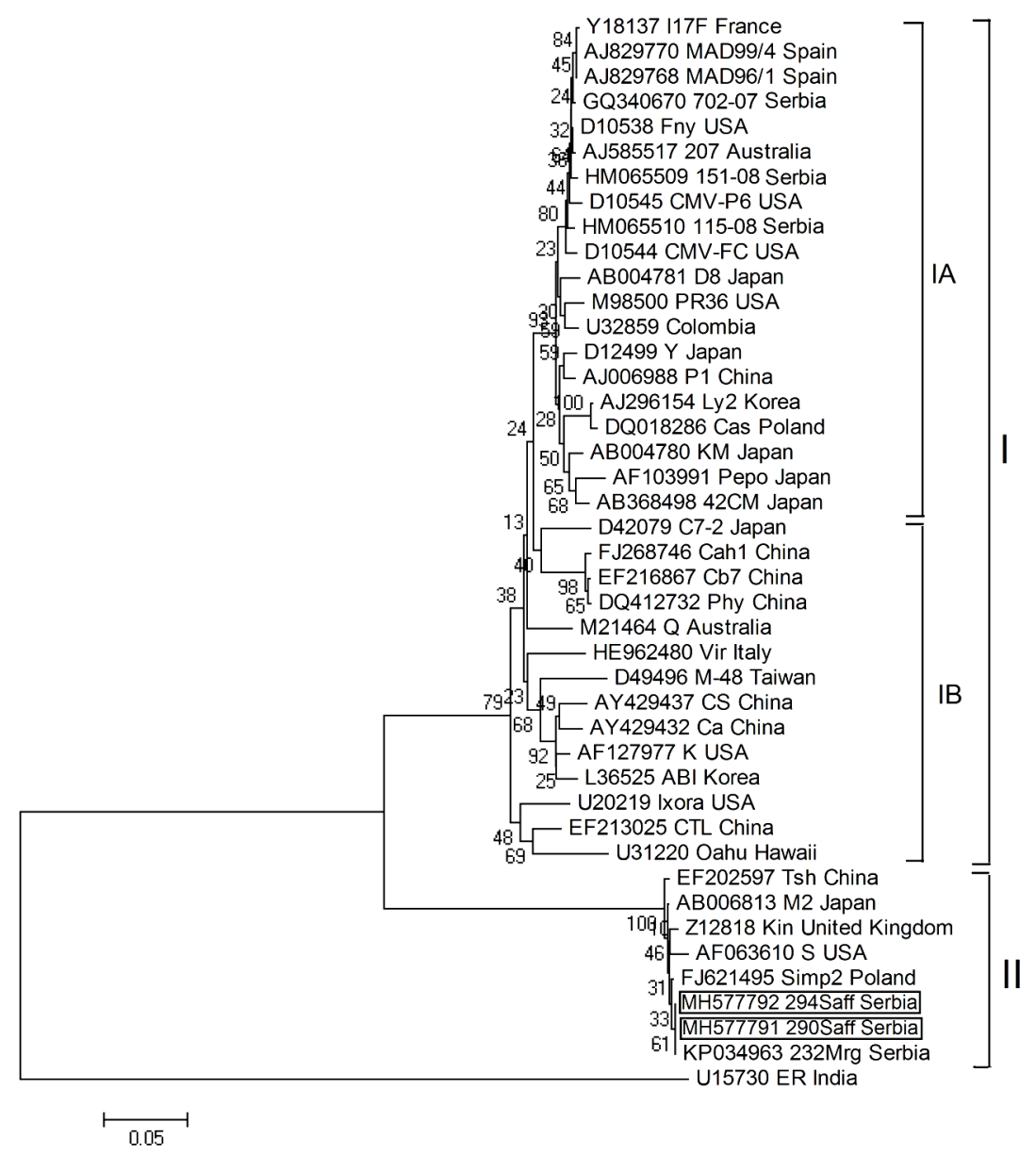

Figure 1. Phylogenetic analysis of cucumber mosaic virus using the neighbour-joining method. The phylogenetic tree was reconstructed based on nucleotide sequences of partial CP sequence of $42 \mathrm{CMV}$ isolates. Phylogram was generated with MEGA5 using bootstrap analysis with 1000 replicates, while the bootstrap values $(>50 \%)$ are shown next to relevant branches. Peanut stunt virus (U15730) was used as the outgroup. The two Serbian isolates from safflower are framed. 
groups: IA, IB and II (Fig. 1), which is in accordance with the previous reports (Palukaitis and Zaitlin, 1997; Roossinck et al., 1999). Subgroup IA comprised CMV isolates from different parts of the world, such as Europe (Spain, Serbia, Poland and France), Asia (Japan, China and Korea), America (USA and Colombia) and Australia which $0.025 \pm 0.004$ genetic diversity among the sequences of this molecular group. Subgroup IB included CMV isolates from Europe (Italy), Asia (Japan, China, Taiwan, and Korea), and America (USA and Hawaii) (0.069 \pm 0.006$)$. Subgroup II contained the selected CMV isolates from safflower from Serbia, as well as the isolates from Asia (Japan and China), North America (USA) and Europe (UK, Poland, and Serbia) (0.007 \pm 0.002$)$. Genetic diversity among three molecular groups was ranging from $0.071 \pm 0.007$ to $0.287 \pm 0.021$. In Serbia, CMV population in the safflower show to be different than CMV population in tobacco and pumpkins, where isolates of CMV belong to the IA subgroup (Stanković et al., 2011; Vučurović et al., 2012). Milošević et al. (2015b) reported the first finding of CMV isolates belonging to subgroup II (231Cal and $232 \mathrm{Mrg}$ ), afterwards the isolates have spread and now can be detected in safflower.

Isolates from subgroup I are considered to be more dominant than the isolates from subgroup II, as they have a wider range of hosts and a higher prevalence (Roossinck et al., 1999; Tian et al., 2009), and therefore lead to greater damage in crops and greater economic losses. Higher prevalence of isolates from subgroup I cause more evident symptoms than the isolates from subgroup II, which is why isolates from subgroup II are harder to notice in the field (Xu et al., 1999; Tian et al., 2009).

Safflower is a very important raw material for industry, especially in medicine and food industry, and the presence of CMV can be a limiting factor for its successful production. Furthermore, as a new CMV host in Serbia, safflower has become a potential natural virus reservoir and an additional source of inoculum. Given that CMV can often appear on various plant species in Serbia, (Petrović et al., 2010; Stanković et al., 2011; Vučurović et al., 2012; Milojević et al., 2013, Milošević et al., 2015b; Nikolić et al., 2018) because of easy transmission in a non-persistent manner by aphids and a wide range of hosts (Garcia-Arenal \& Palukaitis, 2008), constant monitoring is required regarding CMV status and their presence in our country.

\section{Conclusion}

This is the first report on the presence of CMV on safflower in Serbia, confirmed using DAS-ELISA tests, and molecular detection by RT-PCR with specific primers. Sequencing of CP gene of the selected isolates from safflower, as well as a suitable phylogenetic analysis, showed the position of Serbian CMV isolates from safflower in CMV population worldwide. Determination of variability within CMV populations found in different plant hosts in Serbia is expected to expand the knowledge of their epidemiology, with the final purpose of establishing and applying efficient control and preventing the introduction of new strains in our country caused by frequent international exchange of plant material.

\section{References}

Akhtar, K.P., Yussouf, M., Saleem, M., Asghar, M.A. \& Nighat, S. (2010). Resistance of Solanum species to Cucumber mosaic virus subgroup IA and its vector Myzus persicae. European Journal of Plant Pathology, 128: 435-450. https://doi.org/10.1007/s10658010-9670-5

Anderson, B.J., Boyce, P.M. \& Blanchard, C.L. (1995). RNA 4 sequences from cucumber mosaic virus subgroup I and II. Gene, 161: 193-194. https://doi.org/10.1016/0378-1119(95)00276-C

Chander Rao, S., Prasada Rao, R.D.V.J, Manoj Kumar, V., Raman, D.S.M., Raoof, A. \& Prasad, R.D. (2003). First report of tobacco streak virus infecting safflower (Carthamus tinctorius) in Maharashtra, India. Plant Disease, 87(11): 1396. DOI: 10.1094/ PDIS.2003.87.11.1396B

Chauhan, L.S. \& Singh, D.R. (1979). Occurrence of mosaic on safflower in northern India. Indian Phytopathology, 32: 301-302.

Chenulu, V.V., Sachchidanandaand, J. \& Prakash, N. (1971). Safflower mosaic. Phytopathology, 71: 129-134. https:// doi.org/10.1111/j.1439-0434.1971.tb03148.x

Dobrinoiu, R., Jurcoane, S., Danaila-Guidea, S., Moraru, M., Dumbrava, M. \& Rosu, A. (2011): The impact of new technological approaches upon establishing production components and yield randament in Carthamus tinctorium L culture. Romanian Biotechnological Letters, 16(2): 6125-6134. https://www.researchgate.net/publication/265205003

Dubey, V., Aminuddin, K. \& Singh, V.P. (2010). Molecular characterization of Cucumber mosaic virus infecting Gladiolus, revealing its phylogeny distinct from the Indian isolate and alike the Fny strain of CMV. Virus Genes, 41: 126-134. DOI: 10.1007/ s11262-010-0483-6

Ekin, Z. (2005). Resurgence of Safflower (Carthamus tinctorius L.) Utilization: A Global View. Journal of Agronomy, 4(2): 83-87. DOI: $10.3923 /$ ja.2005.83.87

Esendal, E. (2001). Safflower production and research in Turkey. $5^{\text {th }}$ International Safflower Conference, Williston, North Dakota, Sidney, Montana, USA: 203-206. https://www.researchgate.net/

publication/268284995

Fletcher, J.D. (2001). New hosts of Alfalfa mosaic virus, Cucumber mosaic virus, Potato virus $Y$, Soybean dwarf virus, and Tomato spotted wilt virus in New Zealand. New Zealand Journal of Crop and Horticultural Science 3: 213-217. DOI: 10.1080/01140671.2001.9514180

Francki, R.I.B., Mossop D.W. \& Hatta T. (1979). Cucumber mosaic virus. CMI/AAB. Description of Plant Viruses, 213: 6. Commonwealth Mycological Institute and Association of Applied Biologists, Kew, UK.

García-Arenal, F. \& Palukaitis, P. (2008). Cucumber mosaic virus. In: Mahy, B. W. J. and van Regenmortel, M. H. V. (eds.), Desk Encyclopedia of Plant and Fungal Virology. Elsevier, Amsterdam, pp. 171-176.

Iqbal, S., Ashfaq, M. \& Shah H. (2011). Biological characterization of Pakistani isolates of Cucumber mosaic cucumovirus (CMV). Pakistan Journal of Botany, 43: 3041-3047.

Jalender, P., Bharati, N. B. \& Anitha, K. (2015). Studies on host range of cucumber mosaic virus in Tomato (Solanum lycopersicum L.). Ecology, Environment and Conservation, 21. Suppl. Issue; 417-420.

Klisiewiez, J.M. (1965). Identity of viruses from safflower. Plant Disease Reporter, 49: 541-545.

Klisiewiez, J.M. (1966). Reactions of safflower to lettuce mosaic virus. Phytopathology, 56: 1354-1356.

Klisiewiez, J.M. (1983). Etiology of severe mosaic and its effect on Safflower. Plant Disease, 67: 112-114

Landau S., Molle G., Foisb N., Friedman S., Barkai D., Decandia M., 
Cabiddu A., Dvasha L. \& Sitzia M. (2005). Safflower (Carthamus tinctorius L.) as a novel pasture species for dairy sheep in the Mediterranean conditions of Sardinia and Israel. Small Ruminant Research, 59: 239-249. https://doi.org/10.1016/ j.smallrumres.2005.05.008

Milojević, K, Stanković, I., Vučurović, A., Ristić, D., Nikolić, D., Bulajić, A. \& Krstić, B. (2012). First report of Cucumber mosaic virus infecting watermelon in Serbia. Plant Disease, 96(11): 1706. DOI:10.1094/PDIS-07-12-0631-PDN

Milojević, K., Stanković, I., Vučurović, A., Ristić, D., Nikolić, D., Bulajić, A. \& Krstić, B. (2013). Biological and molecular characterization of Cucumber mosaic virus infecting watermelon in Serbia. Zaštita bilja, 64(1), 283: 14-25.

Milošević, D., A. Marjanović-Jeromela, D. Jovičić, M. Ignjatov, Z. Nikolić, S. Terzić \& I. Stanković (2015a). First Report of Alfalfa mosaic virus on Safflower in Serbia. Plant Disease, 99(6): 896. DOI:10.1094/PDIS-12-14-1267-PDN

Milošević, D., Ignjatov, M., Nikolić, Z., Gvozdanović-Varga, J., Petrović, G., Stanković, I. \& Krstić, B. (2015b). First Report of Cucumber mosaic virus causing chlorotic mottle on Pot Marigold (Calendula officinalis) in Serbia. Plant Disease, 99(5): 736. DOI: 10.1094/PDIS-11-14-1208-PDN

Nikolić, D., Vučurović, A., Stanković, I., Radović, N., Zečević, K., Bulajić, A. \& Krstić, B. (2018). Viruses affecting tomato crops in Serbia. European Journal of Plant Pathology,152(1): 225-235. DOI: 10.1007/s10658-018-1467-y

Palukaitis, P., Roossinck, M., Dietzgen, R.G. \& Francki, R.I.B. (1992). Cucumber mosaic virus. Advances in Virus Research, 41: 281-348.

Palukaitis, P. \& Zaitlin, M. (1997). Replicasemediated resistance to plant virus diseases. Advances in Virus Research, 48: 349-377.

Palukaitis, P. \& Garcia-Arenal, F. (2003). Cucumoviruses. Advances in Virus Research, 62: 241-323.

Patil, M.B., Shinde, Y.M. \& Attarde, K.A. (1993). Evaluation of safflower cultures for resistance to Alternaria leaf spot (Alternaria carthami) and management strategies Proceedings of the 3 rd International Safflower Conference, Beijing. In: Li D., Yuanzhou H., Eds., pp. 269-278.

Petrović, D., Bulajić, A., Stanković, I., Ignjatov, M., Vujaković, M. \& Krstić, B. (2010): Presence and distribution of pepper virus in Serbia. Ratarstvo i Povrtarstvo, 47(2): 567-576.
Ravinder, T., Govinda Rao, N. \& Sastry, K.S. (1992). Effect of homeopathic drugs on Cucumber mosaic virus infection in Safflower. Indian Journal of Virology, 8(1): 40-44.

Roossinck, M.J., Zhang, L. \& Hellwald, K. (1999). Rearrangements in the 5 ' nontranslated region and phylogenetic analyses of cucumber mosaic virus RNA 3 indicate radial evolution of three subgroups. Journal of Virology, 73: 6752-6758.

Singh, D., Naqvi, Q.A. \& Garg, J.D. (1999). A strain of cucumber mosaic cucumovirus causing mosaic in marigold in India. Indian Phytopathology, 52(2): 114-117.

Stanković, I., Bulajić, A., Vučurović, A., Ristić, D., Milojević, K., Berenji, J. \& Krstić, B., (2011). Status of tobacco viruses in Serbia and molecular characterization of Tomato spotted wilt virus isolates. Acta Virologica, 55: 337-347. DOI:10.4149/ av_2011_04_337

Tamura, K., Peterson, D., Peterson, N., Stecher, G., Neiand, M. \& Kumar, S. (2011). MEGA5: Molecular evolutionary genetics analysis using maximum likelihood, evolutionary distance, and maximum parsimony methods. Molecular Biology and Evolution, 28: 2731-2739. https://doi.org/10.1093/molbev/msr121

Thompson, J.D., Higgins, D.G. \& Gibson, T.J. (1994). CLUSTAL W: Improving the sensitivity of progressive multiple sequence alignment through sequence weighting, position specific gap penalties and weight matrix choice. Nucleic Acids Research 22: 4673-4680. DOI:10.1093/nar/22.22.4673

Tian, Z., Jiyan, Q., Jialin, Y., Chenggui, H. \& Weicheng, L. (2009). Competition between Cucumber mosaic virus subgroup I and II isolates in tobacco. Journal of Phytopathology, 157: 457-464. https://doi.org/10.1111/j.1439-0434.2008.01531.x

Vučurović, A., Bulajić, A., Stanković, I., Ristić, D., Berenji, J., Jović, J. \& Krstić, B. (2012). Non-persistently aphid-borne viruses infecting pumpkin and squash in Serbia and partial characterization of Zucchini yellow mosaic virus isolates. European Journal of Plant Pathology, 133: 935-947. https://doi.org/10.1007/ s10658-012-9964-x

Xu, P., Li, M., Lin, Q \& Xie, L. (1999). Comparative studies on properties of five Cucumber mosaic virus isolates infecting Passiflora in China. Virologica Sinica, 14: 73-79

\section{Prisustvo i molekularna karakterizacija virusa mozaika krastavca u usevu šafranike u Srbiji}

\section{Dragana Milošević · Maja Ignjatov · Ana Marjanović Jeromela $\cdot$ Zorica Nikolić · Gordana Tamindžić · Dragana Miljaković · Ivana Stanković}

Sažetak: Šafranika (Carthamus tinctorius L.) predstavlja jednu od važnih uljanih kultura koja pripada familiji Asteraceae. Tokom 2015. godine, prikupljeno je 46 uzoraka biljaka šafranike poreklom iz Srbobrana koji su serološki testirani na prisustvo virusa mozaika krastavca (cucumber mosaic virus, CMV), virusa mozaika lucerke (alfalfa mosaic virus, AMV) i virusa mozaika salate (lettuce mosaic virus, LMV) korišćenjem komercijalnih kitova za DAS-ELISA test. U prikupljenim uzorcima dokazano je prisustvo CMV i AMV, dok prisustvo LMV nije dokazano ni u jednom od testiranih uzoraka. Prisustvo CMV je dalje potvrđeno mehaničkim inokulacijama test biljaka Chenopodium quinoa, C. amaranticolor, Nicotiana glutinosa i Datura stramonium kao i na C. tinctorius, čime je potvrđena infektivna priroda oboljenja. Molekularna detekcija CMV obavljena je amplifikacijom fragmenta dužine $871 \mathrm{bp}$ kod svih ispitivanih izolata korišćenjem specifičnih prajmera CMVCPfwd/CMVCPrev koji omogućavaju umnožavanje celog CP gena kao i delove 5' i 3' UTR. U cilju dalje identifikacije, RT-PCR produkti izolata 290Saff i 294Saff su sekvencionisani (MH577791 i MH577792) i upoređeni sa CMV sekvencama dostupnim u GenBank bazi podataka. Filogenetska analiza na osnovu sekvence CP gena pokazala je grupisanje odabranih izolata u tri podgrupe, IA, IB i II. Izolati CMV iz šafranike poreklom iz Srbije grupisali su se u podgrupu II. Prema našim saznanjima, ovo je prvi izveštaj o prisustvu CMV na biljkama šafranike u Srbiji koji može da nanese veliku štetu u proizvodnji ove biljne vrste, a takođe predstavlja pretnju drugim ekonomski značajnim gajenim biljnim vrstama u Srbiji.

Ključne reči: DAS-ELISA, RT-PCR, šafranika, virus mozaika krastavca 